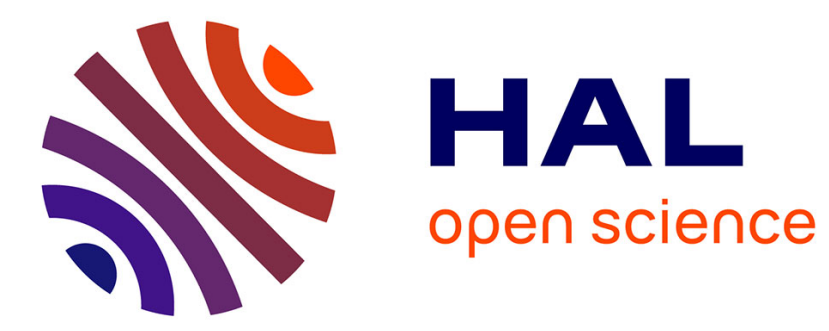

\title{
Market Structure and the Cost of Capital
}

Mohamed El Hedi Arouri, Christophe Rault, Ana Maria Sova, Robert Sova, Frédéric Teulon

\section{To cite this version:}

Mohamed El Hedi Arouri, Christophe Rault, Ana Maria Sova, Robert Sova, Frédéric Teulon. Market Structure and the Cost of Capital. 2013. hal-00798048

\section{HAL Id: hal-00798048 \\ https://hal.science/hal-00798048}

Preprint submitted on 7 Mar 2013

HAL is a multi-disciplinary open access archive for the deposit and dissemination of scientific research documents, whether they are published or not. The documents may come from teaching and research institutions in France or abroad, or from public or private research centers.
L'archive ouverte pluridisciplinaire HAL, est destinée au dépôt et à la diffusion de documents scientifiques de niveau recherche, publiés ou non, émanant des établissements d'enseignement et de recherche français ou étrangers, des laboratoires publics ou privés. 


\title{
Market Structure and the Cost of Capital
}

\author{
Mohamed El Hedi Arouri \\ CRCGM-Université d'Auvergne \& EDHEC Business School \\ Mohamed.Arouri@edhec.edu \\ Christophe Rault \\ LEO-Université d'Orléans and BEM Bordeaux Management School \\ chrault@hotmail.com
}

Anamaria Sova

CES, Sorbonne University, and E.B.R.C

anamariasova@yahoo.fr

Robert Sova

CES, Sorbonne University, A.S.E. and E.B.R.C

robertsova@yahoo.com

\section{Frédéric Teulon}

IPAG Business School, IPAG - Lab

f.teulon@ipag.fr

\begin{abstract}
We contribute to the finance literature in two main ways. First, we present a theoretical capital asset pricing model (CAPM) to price assets in different market structures. Second, we use our model to analyze whether when markets are partially segmented using the local or the global CAPM yields significant errors in the estimation of the cost of capital for a sample of firms from developed and emerging countries.
\end{abstract}

JEL classification: G15, F36, C32.

Keywords: Finance, International Asset Pricing, Firm's Cost of Capital, Segmentation. 


\section{1- Introduction}

In recent years, both developed and emerging capital markets have experienced numerous changes including removal of investment barriers, economic reforms, introduction of country funds and depository receipts (DRs) as well as other financial innovations. One of the aims of these changes is to develop financially integrated stock markets. Indeed, a move towards integrated stock markets should lead to a lower cost of capital, greater investment opportunities, and higher savings and growth made possible by international risk sharing [Stulz (1999), Bekaert and Harvey (2003) and Carrieri et al. (2007)]. The same period has known a succession of severe crises of different origins and effects. Apart the 1997-1998 Asian crisis and the 2001 US recession, the 2007-2009 global crisis, sparked by subprime mortgage defaults in the US, has strongly affected financial markets of almost all emerging and developed countries. These changes have increased the exposure of national markets to global risk factors as well as their degree of integration into the world market. However, since today's national markets are neither perfectly integrated nor strictly segmented market [Bekaert and Harvey (1995) and Carrieri et al. (2007)]. Investigating the effects of these integrating changes on the international risk and return trade-off and cost of capital of firms is crucial for rational decision-making and capital budgeting. In this paper, we introduce a theoretical international capital asset pricing model (CAPM) for partially segmented stock markets and use it to assess, under the hypothesis of partial segmentation, the pricing errors made by investors who use domestic or global asset pricing models to price assets and compute the cost of capital of firms.

Our model permits to investigate the consequences of changes in the degree of stock market integration on the cost of capital of firms and the prices of assets under different market structures. If capital markets are fully integrated, investors face common and country-specific risks, but price only common risk factors because country-specific risk is fully diversified internationally. In this case, the same asset pricing relationship (the global model) applies in all countries and expected returns should be determined solely by global risk factors. In contrast, when capital markets are strictly segmented the asset pricing relationship (the domestic model) varies from one country to another and domestic risk factors determine expected returns. In other words, given their exposure to systematic global risk, assets traded in different locations will yield different expected returns [Karolyi and Stulz (2002)]. When capital markets are 
partially segmented, investors face both common and country-specific risks and price them both. In this case, expected returns should be determined by a combination of local and global risk sources. Thus, the degree of integration determines the value of the risk premium expected on different assets and thus the prices of asset as well as the cost of capital of firms.

Stock market integration dynamic is affected by both institutional and behavioral factors. First, financial integration is a result of economic, institutional, legal and political factors. In particular, integration depends on the harmonization of stock exchange rules and the ability of foreign investors to access domestic assets as well as the ability of domestic investors to access foreign investment opportunities. In fact, access to worldwide investment opportunities, through direct means and homemade diversification, increases the exposure of domestic assets to global factor and therefore improves the national stock market integration level. However, we should mention that although regional and international harmonization of exchange trading rules encourages greater investor activity, it often allows flexibility in the implementation of clauses and therefore this partially harmonization could create partially integrated markets [Cumming et al. (2011)]. Second, behavioral factors such as risk aversion, relative optimism, and information perception may also affect the desire to invest abroad and thus market integration. Therefore, even in the absence of institutional barriers to international investments, indirect barriers can still discourage foreign investors and prevent world stock market integration. Thus, the process of stock market integration is complex, gradual and takes years, with occasional reversals and most domestic stock markets should be between the two theoretical extremes of strict segmentation (integration zero) and perfect integration [Bekaert and Harvey (1995), Carrieri et al. (2007) and Arouri et al. (2010,2012)]. Therefore, assessing the degree of market integration can appropriately be addressed only within the context of an international capital asset pricing model.

In the recent decades, the management science and operational research literature has introduced new theoretical works in the field of risk-return trade-off and asset pricing in different market structures [Bell (1995), Pedersen (2000), Huang (2008) and references therein]. Overall, one can classify the available models in two categories: theoretical domestic asset pricing models in which it is assumed that markets are strictly segmented [Sharpe (1964) and Ross (1976) among others] and theoretical international asset pricing models in which it is assumed that markets are perfectly integrated [Adler 
and Dumas (1983), Grauer et al. (1976), and Solnik (1974, 1983) among others]. However, there are no theoretical asset pricing models for partially segmented markets, except those developed in the vein of Black (1974) and Errunza and Losq (1985) in which a specific investment barrier is generally introduced and its effects on the equilibrium returns are derived. ${ }^{1}$ For instance, Black (1974) presents a model of international asset pricing in the case of partially segmented markets. The author develops a two country-model in the presence of explicit barriers to international investment in the form of a tax on holdings of assets in one country by foreigners. This model was extended by Stulz (1981) and Cooper and Kaplanis (2000). The authors show that capital budgeting rules depend largely on the level of taxes that discourage the foreign investors from investing internationally. A more general two-country model is proposed by Errunza and Losq (1985) (EL-85 hereafter). This model enables to characterize the mild segmentation of domestic markets. However, some of its hypotheses are too restrictive. In fact, the authors assume that all domestic assets can be traded by all investors (both domestic and foreign investors), whereas foreign assets are not accessible to domestic investors because of restrictions imposed by the foreign government. EL-85 show that the foreign assets are priced according to the traditional global CAPM, but there is a super risk premium, proportional to the conditional market risk, for the restricted assets.

Errunza and Losq (1989) (EL-89 hereafter) extend the EL-85 model to a multicounty framework. However, alike EL-85 the authors reduce segmentation factors to the only effects of capital flow restrictions and thus their model is again built on a simple explicit formalization of segmentation factors. More precisely, they distinguish between two types of securities: securities that can be traded by any investor in the world (the core of the market), and restricted securities (the periphery of the market constituted of $N$ segments such that no investor can trade on more than one segment). No cross-investment between segments in the periphery is allowed and investors in the core are denied access to the periphery segments. Thus, segments (countries) in the periphery are assumed to be completely segmented. The authors establish that in a

\footnotetext{
1 Other ICAPMs with similar barriers to international capital flows include those of Eun and Janakiraman (1986), Uppal (1993), Bailey and Jagtiani (1994), Basak (1995) and Stulz and Wasserfallen (1995), and Easley and O'Hara (2004). For more works on portfolio and market efficiency, please see Dragota and Mitrica (2004), Charles (2010), Guesmi and Nguyen (2011) and Clark et al. (2011) and references therein.
} 
number of cases, their multi-country model leads to significantly different asset pricing relationships compared to the EL-85 two-country model. In particular, it allows analysis of integrative changes in the world market structure.

Nevertheless, stock market integration is a complex and gradual process involving many different kinds of explicit and implicit barriers, and the models discussed above are clearly not flexible enough to investigate the complexities of the market integration. In the absence of an established theoretical model that specifies the economic mechanism moving a market from segmentation to integration, Bekaert and Harvey (1995) propose a purely empirical model of time-varying market integration that allows for the relative importance of global and domestic information on stock returns to change over time. This model is simply an econometric combination of a domestic CAPM and an international one. The integration measure is modelled as a function of national and global variables. An alternative ad-hoc model is developed by Carrieri et al. (2007) who adopt a time-varying version of two-country EL-85 model. The results of the empirical tests confirm the findings of previous works and argue that developed markets are highly integrated in the world market while emerging markets have low integration degrees [Bhattacharya and Daouk (2002), Adler and Qi (2003) and Hardouvelis et al. (2006)].

The current paper aims to fill this gap by introducing a more flexible theoretical international CAPM in order to understand the complex mechanisms that move a national stock market from segmentation to integration and to investigate the effects of this transformation on the cost of capital of firms and on the prices of assets. Instead of imposing restrictions on assets as in all previous models, we hypothesize that there are different types of investors and assume simply that some investors do not want and/or do not have access to foreign assets as a result of explicit and/or implicit barriers on inflows and/or outflows, barriers which may make markets partially segmented. Starting from that, we derive the equilibrium asset pricing relationship and investigate the effects of changing market structures on the prices of assets and the cost of capital of firms. The main theoretical implication of our model is that if investors do not hold all international assets, the world market portfolio is not efficient and the traditional global CAPM must be augmented by a new factor which reflects the proportion of the domestic risk undiversifiable internationally because of segmentation. The more integrated the markets, the greater the decrease in the premium required on this additional risk factor, and the lower the cost of capital. If markets are perfectly 
integrated, our model converges to the traditional global CAPM. Therefore, unlike the available theoretical CAPMs for partially integrated markets [Black (1974) and El-85, EL-89 and the models developed along these lines], our model posits that if a group of investors fails to hold the world market portfolio because of explicit and/or implicit barriers on inflows and/or outflows, the remaining investors will also be unable to hold the world portfolio and thus a part of the domestic risk can be priced to compensate rational global investors for the inability to hold the well diversified world market portfolio.

The Figure 1 illustrates the main issues examined in this paper as well as our contribution to previous works on stock market integration and asset pricing models. The partial integration of national stock markets is the maintained hypothesis and thus asset returns are determined by a combination of local and global risk factors. ${ }^{2} \mathrm{We}$ contribute to the financial literature by introducing a theoretical CAPM to directly price assets in that context. A pricing error may arise from an individual firm if the domestic CAPM (which prices directly local risk factors and potentially indirectly global factors through their effects on local factors) or the global CAPM (which prices directly global risk factors and potentially indirectly local factors through their effects on global factors) is used to compute the cost of capital instead of the partially segmented CAPM (which prices directly both local and global risk factors). The size of this pricing error depends on the degree of integration. We contribute to previous works by assessing these pricing errors for a sample of firms from developed and emerging countries. Indeed, our paper is the first to assess the pricing errors made when markets are partially segmented but investors use domestic or global models to compute the cost of capital of firms [Stulz (1995) and Koedijk et al. (2002)].

\footnotetext{
${ }^{2}$ Indeed, all empirical studies confirm that the two extreme cases of strict segmentation and perfect integration are rejected and that markets are actually partially segmented, but at different levels [Karolyi and Stulz (2002), Bekaert and Harvey (2002), Bekaert et al. (2003) and Stulz (2005)].
} 


\section{Figure 1 \\ Local, global and mixed computation of the cost of capital}

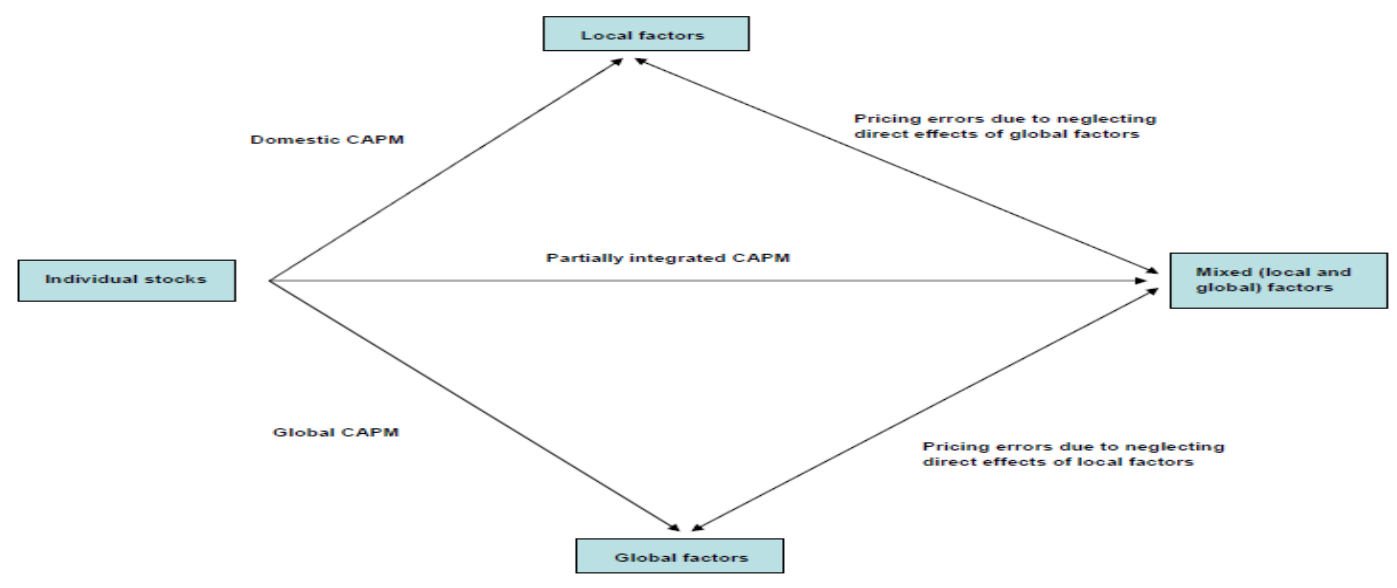

The remainder of the paper is organized as follows. In section 2, we introduce our model and discuss its main implications. Section 3 assesses the pricing errors that arise if the domestic or the global CAPMs are used instead of our model to compute the cost of capital of firms. Concluding remarks and future extensions are in section 4.

\section{2- Market Structure and Asset Pricing}

First, we introduce our hypotheses and main notation. Second, we derive the wellknown traditional global CAPM in the case of perfectly integrated markets. In this context, investors are assumed to be homogenous and are able to hold every asset in the market portfolio. Their holdings will be similar in the equilibrium. They divide their wealth between the risk-free asset and the market portfolio which contains all the available risky assets. Third, we impose restrictions on investors' choices and derive their impacts on the equilibrium asset pricing relationship. In that context, we show that the available world market portfolio is not efficient and the traditional global CAPM does not hold. The available world market portfolio is less diversified than the actual market portfolio which would contain all the weighted national risky assets if markets were perfectly integrated. Thus, investors fail to form efficient portfolios and violate the two-fund separation theorem. We show that when assets are priced using the available world market portfolio, a part of the domestic risk should be priced in order to remunerate the world investors for holding the inefficient international portfolio rather than the actual well diversified portfolio. Finally, we compare our partially integrated model to the other extreme case of strict market segmentation. 


\subsection{Hypotheses and notation}

We consider a world in which:

- There are $c$ countries and $c$ risky assets (one asset from each country) ${ }^{3}$.

- There are $l+1$ types of investors; different types of investors may exist in each country. Investors of type $j(j=0,1, \ldots, l)$ have no access to $k_{j}\left(0 \leq k_{j}<c\right)$ assets, i.e. investors of type $j$ have access to $c-k_{j}$ assets; they have at least access to their domestic assets. Denote by $n_{j}$ the number of investors of type $j$ and $n=\sum_{j=0}^{l} n_{j}$ the total number of investors. In addition, let $k_{0}=0 .{ }^{4}$

- Purchasing power parity (PPP) holds or that PPP does not hold but that the equilibrium price of currency risk is equal to zero. ${ }^{5}$

- Asset returns are normally distributed or the investor's utility is quadratic. Thus, investors consider only the two fist moments. Suppose that the investor $j$ has the following utility function $V\left(W_{j}^{f}\right)$ :

$$
V\left(W_{j}^{f}\right)=E\left(W_{j}^{f}\right)-\frac{\delta}{2} \operatorname{Var}\left(W_{j}^{f}\right)
$$

where $w_{j}^{f}$ is the investor $j$ 's future wealth, $\delta$ the risk aversion coefficient. ${ }^{6}$ The budget constraint of the investor $j$ can be written as:

$$
W_{j}^{f}=W_{j}^{i}(1+r)+D_{j}^{\prime}(\underline{R}-r \underline{1})
$$

\footnotetext{
${ }^{3}$ The number of studied assets does not affect our final results.

${ }^{4}$ Investors of type 0 are investors who have access to assets from most countries via direct investment, multinational firms, and DRs.

${ }^{5}$ PPP is one of the most heavily studied subjects in international finance and macroeconomics. Despite extensive research, however, the empirical evidence on PPP remains inconclusive even if recent studies using nonlinear econometric techniques generally support PPP [Chortareas and Kapetanios (2009) and Zhou and Kutan (2011) and references within].

${ }^{6}$ Most of the recent works on portfolio selection have been done based on only the first two moments of return distributions [Wang and Forsyth (2011) and references therein]. Theoretical and empirical justifications of this assumption can be found in numerous recent works such as Basak and Chabakauri (2010), Levy (2010) and Johnstone and Lindley (2011). However, we should notice that there is a controversy over the issue of whether higher moments should be considered in portfolio selection [Li et al. (2011) and references therein].
} 
where $W_{j}^{i}$ is the initial wealth, $r$ the risk free rate and $\underline{R}$ such as $\underline{R}^{\prime}=\left(R_{1}, R_{2}, \ldots, R_{c}\right)$ is the vector of returns of the $c$ national risky assets. ${ }^{7} \underline{D}_{j}{ }_{j}=\left(d_{j}^{1}, d_{j}^{2}, \ldots, d_{j}^{c}\right)$ is the vector of investor $j$ 's amount invested in the $c$ national risky assets expressed in the currency of the reference country. ${ }^{8}$

\section{2- Complete integration}

Assume here that markets are perfectly integrated and that investors access all international investment opportunities. In other words, investors from each country are of type $k_{0}$. For the investor $j$, the maximization of utility subject to budget constraint drives to the following demand function:

$$
\underline{D}_{j}=\frac{1}{\delta} \underline{\underline{\Omega}}^{-1}(E(\underline{R})-r \underline{1})
$$

where $\underline{\underline{\Omega}}$ is the variance-covariance matrix of the $c$ national risky assets.

The total demand for the $c$ risky assets is obtained by summing the demands of the $n$ investors. In market equilibrium, the total demand is equal to the total supply of the $c$ risky assets $\underline{S}^{\prime}=\left(s_{1}, s_{2}, \ldots, s_{c}\right)$.

The equilibrium expected excess returns on the risky assets can thus be written as:

$$
E(\underline{R})-r \underline{1}=\frac{\delta}{n} \underline{\underline{\Omega}} \underline{S}
$$

Let $C=\underline{S^{\prime}} 1$ be the world market capitalization expressed in the reference country currency and $\underline{\alpha}=\frac{\underline{S}}{C}$ be the vector of proportions of the $c$ risky assets in the

\footnotetext{
${ }^{7}$ Hereafter $\underline{X}$ denotes a vector and $\underline{\underline{X}}$ denotes a matrix.

${ }^{8}$ Without loss of generality, we consider that the currency of the $c^{\text {th }}$ country is the reference currency.
} 
world stock market. The expected return on the world market is then $E\left(R_{w}\right)=\underline{\alpha}^{\prime} E(\underline{R})$ and its variance is $\sigma_{w}^{2}=\underline{\alpha} \underline{\underline{\Omega}} \underline{\alpha}$. The vector of betas of the $c$ risky assets is given by: $\underline{\beta}=\frac{1}{\sigma_{w}^{2}} \underline{\underline{\Omega}} \underline{\alpha}$.

Next, multiply equation (4) by $\underline{\alpha}^{\prime}$ :

$$
\underline{\alpha^{\prime}} E(\underline{R})-r \underline{\alpha^{\prime}} \underline{1}=\frac{\delta}{n} \underline{\alpha}^{\prime} \underline{\underline{\Omega}} \underline{\underline{S}}=\frac{\delta}{n} \underline{\alpha^{\prime}} \underline{\underline{\Omega}} \underline{\alpha} C
$$

Equation (5) can be written as:

$$
E\left(R_{w}\right)-r=\frac{\delta}{n} \sigma_{w}^{2} C
$$

Substituting equation (6) into equation (4), we obtain the following relation:

$$
E(\underline{R})-r \underline{1}=\frac{1}{\sigma_{w}^{2}} \underline{\underline{\Omega}} \underline{\alpha}\left(E\left(R_{w}\right)-r\right)
$$

It leads to the traditional global CAPM:

$$
E(\underline{R})-r \underline{1}=\underline{\beta}\left(E\left(R_{w}\right)-r\right)
$$

For a particular asset $i$, equation (8) can be written as follows:

$$
E\left(R_{i}\right)-r=\beta_{i}\left(E\left(R_{w}\right)-r\right)
$$

Finally, we can write (9) as:

$$
E\left(R_{i}\right)-r=\lambda \operatorname{Cov}\left(R_{i}, R_{w}\right)
$$

where $\lambda=\frac{E\left(R_{w}\right)-r}{\sigma_{w}^{2}}$ is the world price of market risk. Merton (1980) argues that $\lambda$ is a measure of the representative investor's relative risk aversion. 
The important message of the traditional global CAPM is that in equilibrium only international market risk, represented by the scaled covariance of stock returns and the world market return, is priced. Domestic risk is not rewarded because it can be diversified. The global CAPM prediction that individuals hold equities from around the world in proportion to market capitalizations is based on the assumption that there are no direct or indirect barriers to international investment. In practice, such barriers do exist.

\section{3- Partial integration}

Stock markets are partially segmented when they are neither strictly segmented nor perfectly integrated. In other words, some investors access all international assets, whereas others access only a limited set of assets. For instance, using DRs and other financial innovations some investors may have access to almost all traded assets in the world while other investors rely on only traditional financial supports and thus access to a limited set of assets. In these conditions, the traditional global CAPM will fail to hold because its main assumptions are violated.

Let $\overline{D_{j}}$ be the $\left(\left(c-k_{j}\right) \times 1\right)$ vector of investor $j$ 's amount (expressed in the reference country currency) invested in the $c-k_{j}$ risky assets to which investors of type $j$ access. We can write this demand as a $(c \times 1)$ vector by setting $\underline{D}_{j}=\underline{J}_{j} \bar{D}_{j}$, where $\underline{J}_{j}$ is a $\left(c \times\left(c-k_{j}\right)\right)$ matrix equal to the $\left(\left(c-k_{j}\right) \times\left(c-k_{j}\right)\right)$ identity matrix augmented by $k_{j}$ zero-lines corresponding to the $k_{j}$ national assets to which investors $j$ do not access.

Let $\underline{\underline{\Omega}}_{j}$ be the $\left(\left(c-k_{j}\right) \times\left(c-k_{j}\right)\right)$ variance-covariance matrix of the $c-k_{j}$ assets to which investors of type $j$ access and $\overline{E(\underline{R})}$ the $\left(\left(c-k_{j}\right) \times 1\right)$ vector of expected returns on these assets. The maximisation of the utility of investors $j$ subject to their budget constraints leads to the following demand function:

$$
\overline{\underline{D}_{j}}=\frac{1}{\delta} \underline{\underline{\Omega}}_{j}^{-1}(\overline{E(\underline{R})}-r \underline{1})
$$


Likewise, we can write this demand function as a $(c \times 1)$ vector using the matrix $\underline{J}_{j}:$

$$
D_{j}=\frac{1}{\delta} J_{j} \Omega_{j}^{-1} J_{j}^{\prime}(E(R)-r \underline{1})
$$

The total demand of the investors for the $c$ risky assets is thus given by:

$$
\underline{D}=n_{0} \underline{D}_{0}+n_{1} \underline{D}_{1}+\ldots+n_{j} \underline{D}_{j}+\ldots+n_{l} \underline{D}_{l}=\sum_{j=0}^{l} n_{j} \underline{D}_{j}
$$

In equilibrium, the total demand is equal to the total supply $\underline{S^{\prime}}=\left(s_{1}, s_{2}, \ldots, s_{c}\right)$, which leads to: ${ }^{9}$

$$
\underline{S}=\frac{1}{\delta}\left[\sum_{j=0}^{l} n_{j} \underline{J}_{j} \underline{\underline{\Omega}}_{j}^{-1}{\underline{\underline{J^{\prime}}}}_{j}\right](E(\underline{R})-r \underline{1})
$$

In this partially integrated framework, the expected excess return on the $c$ risky assets is given by:

$$
E(\underline{R})-r \underline{1}=\frac{\delta}{n}\left[\sum_{j=0}^{l} \frac{n_{j}}{n} \underline{J}_{j} \stackrel{\Omega}{=}_{j}^{-1}{\underline{\underline{J^{\prime}}}}_{j}\right]^{-1} \underline{S}
$$

\section{Proposition 1}

Compared to equation (4), equation (15) shows that because of market segmentation the covariance-variance matrix of the c risky assets $\underline{\underline{\Omega}}$ is replaced in the world equilibrium relationship by the adapted matrix $\left[\sum_{j=0}^{l} \frac{n_{j}}{n} \underline{J}_{j} \underline{\underline{\Omega}}_{j}^{-1}{\underline{\underline{J}^{\prime}}}_{j}\right]^{-1}$. If investors access all international assets, this matrix would simply be equal to $\underline{\underline{\Omega}}$ as in the case of perfectly integrated markets.

However, market segmentation should particularly affect the total supply of the $c$ risky assets. In fact, equation (15) can also be written as:

\footnotetext{
${ }^{9}$ Note that $\underline{\underline{J}}_{0}=\underline{\underline{I}}$ and $\underline{\underline{\Omega}}_{0}=\underline{\underline{\Omega}}$.
} 


$$
E(\underline{R})-r \underline{1}=\left(\frac{\delta}{n} \underline{\underline{\Omega}}\right)\left(\underline{\underline{\Omega}}^{-1}\left[\sum_{j=0}^{l} \frac{n_{j}}{n} \underline{J}_{j} \underline{\underline{\Omega}}_{j}^{-1}{\underline{\underline{J^{\prime}}}}_{j}\right]^{-1} \underline{S}\right)
$$

\section{Proposition 2}

Equation (16) says that because of segmentation, the total supply $\underline{S}$ is replaced in the equilibrium valuation relationship by an adjusted supply function: $\underline{\underline{\Omega}}^{-1}\left[\sum_{j=0}^{l} \frac{n_{j}}{n} \underline{J}_{j} \underline{\underline{\Omega}}_{j}^{-1}{\underline{\underline{J^{\prime}}}}_{j}\right]^{-1} \underline{S}$. Therefore, investors are subject to an altered world market portfolio. ${ }^{10}$ The traditional global CAPM continues to hold with regard to this altered portfolio but it does not hold with regard to the actual world market portfolio. By contrast, if markets were perfectly integrated and investors access all international assets, the supply function would be equal to $\underline{S}$ and the traditional global CAPM will hold with regard to the actual world market portfolio. The greater the segmentation of the market, the greater the difference from $\underline{S}$ of the supply function used in the equilibrium valuation relation.

Equation (15) can also be written as:

$$
E(\underline{R})-r \underline{1}=\frac{\delta}{n}\left[\underline{\underline{\Omega}}^{-1}-\sum_{j=1}^{l} \frac{n_{j}}{n}\left(\underline{\underline{\Omega}}^{-1}-\underline{J}_{j} \underline{\underline{\Omega}}_{j}^{-1}{\underline{\underline{J^{\prime}}}}_{j}\right)^{-1} \underline{S}\right.
$$

By applying the well known Sherman-Morrison-Woodbury matrix identity, equation (17) leads to:

$$
E(\underline{R})-r \underline{1}=\frac{\delta}{n}\left[\underline{\underline{\Omega}}+\underline{\underline{\Omega}}\left(\sum_{j=1}^{l} \frac{n_{j}}{n}\left[\underline{\underline{\Omega}}^{-1}-\underline{J}_{j} \underline{\underline{\Omega}}_{j}^{-1}{\underline{\underline{J^{\prime}}}}_{j}\right]^{-1}-\underline{\underline{\Omega}}\right)^{-1} \underline{\underline{\Omega}}\right] \underline{S}
$$

Equation (18) can also be written as:

\footnotetext{
${ }^{10}$ This portfolio cannot be constructed in empirical tests without making strong assumptions on the distributions of domestic investors among the different groups. However, in empirical studies authors use the return on the actual portfolio and thus the traditional global CAPM does not hold. Then their results must be taken with precaution [Harvey (1991), De Santis and Gérard (1997) among others].
} 


$$
E(\underline{R})-r \underline{1}=\frac{\delta}{n}\left[\underline{\underline{\Omega}}+\underline{\underline{\Omega}}\left(\sum_{j=1}^{l} \frac{n_{j}}{n}\left[\underline{\underline{I}}-\underline{\underline{J}}_{j} \underline{\underline{\Omega}}_{j}^{-1}{\underline{\underline{J^{\prime}}}}_{j}\right]^{-1}-\underline{\underline{I}}\right)^{-1}\right] \underline{S}
$$

This equation can be simplified as follows:

$$
E(\underline{R})-r \underline{1}=\frac{\delta}{n} \underline{\underline{\Omega}} \underline{S}+\frac{\delta}{n} \sum_{j=1}^{l} n_{j} \underline{\underline{\Omega}} \underline{\underline{\Psi}} \underline{S}
$$

where $\underline{\underline{\Psi}}=\left(\sum_{j=1}^{l} n_{j}\left[\left[1-\frac{n_{0}}{n}\right]\left[\underline{\underline{I}}-\underline{\underline{J}}_{j} \underline{\underline{\Omega}}_{j}^{-1}{\underline{\underline{J^{\prime}}}}_{j}\right]^{-1}-\underline{\underline{I}}\right]\right)^{-1}$.

Next, multiply equation (20) by the vector of capitalisations $\left(\underline{\alpha^{\prime}}\right)$ and use $\underline{\alpha}=\frac{\underline{S}}{C}$, we obtain:

$$
E\left(R_{w}\right)-r=\frac{\delta}{n} \sigma_{w}^{2} C+\frac{\delta}{n} \sum_{j=1}^{l} n_{j} \sigma_{w}^{2} \underline{\beta} \underline{\Pi} C
$$

where $\underline{\Pi}=\underline{\underline{\Psi}} \underline{\alpha}$.

Now, substituting (21) into (20), we have:

$$
E(\underline{R})-r \underline{1}=\left(E\left(R_{w}\right)-r\right)\left(1+\sum_{j=1}^{l} n_{j} \underline{\beta} \underline{\Pi}\right)^{-1} \underline{\beta}+\sum_{j=1}^{l} n_{j} \frac{E\left(R_{w}\right)-r}{\sigma_{w}^{2}}\left(1+\sum_{j=1}^{l} n_{j} \underline{\beta} \underline{\Pi}\right)^{-1} \underline{\underline{\Omega}} \underline{\Pi}
$$

Equation (22) can be simplified as follows:

$$
E(\underline{R})-r \underline{1}=\underline{\beta}\left(E\left(R_{w}\right)-r\right)+\frac{\sum_{j=1}^{l} n_{j}}{1+\sum_{j=1}^{l} n_{j} \underline{\beta} \underline{\Pi}} \frac{E\left(R_{w}\right)-r}{\sigma_{w}^{2}}\left[\underline{\underline{\Omega}} \underline{\Pi}-\sigma_{w}^{2} \underline{\beta} \underline{\beta} \underline{\underline{\Pi}}\right]
$$

This finally leads to our Partially Segmented CAPM:

$$
E(\underline{R})-r \underline{1}=\underline{\beta}\left(E\left(R_{w}\right)-r\right)+\lambda \underline{\underline{\Omega}}^{d} \underline{\Pi} \varphi
$$


where $\varphi=\frac{\sum_{j=1}^{l} n_{j}}{1+\sum_{j=1}^{l} n_{j} \underline{\beta} \underline{\Pi}}$ is a parameter which reflects the international stock market structure. When market segmentation is weak and the number of constrained investors is insignificant, $\varphi \cong 0$. The term $\underline{\underline{\Omega}}^{d}=\left[\underline{\underline{\Omega}}-\sigma_{w}^{2} \underline{\beta} \underline{\beta}^{\prime}\right]$ measures the domestic risk unrelated to international portfolio market. In perfectly integrated markets, this risk is not rewarded because it is eliminated by international portfolio diversification. However, equation (24) says that because of stock market segmentation a part of this domestic risk is internationally priced. We call this part "undiversifiable domestic risk" which, as shown by equation (24), is measured by $\underline{V}^{\varepsilon}=\underline{\underline{\Omega}}^{d} \underline{\Pi} \varphi$.

More interesting, equation (27) shows also that the price of this international undiversifiable domestic risk is equal to the world price of market risk $(\lambda)$. In other words, this risk is translated into a risk premium comparable to that required on world market risk.

For a particular asset $i$, equation (24) can be written as follows:

$$
E\left(R_{i}\right)-r=\beta_{i}\left(E\left(R_{w}\right)-r\right)+\lambda(\pi \varphi)_{i} \omega_{i}^{\varepsilon}
$$

where $\omega_{i}^{\varepsilon}=\sigma_{i}^{2}-\beta_{i}^{2} \sigma_{w}^{2}$ is the domestic risk unexplained by the traditional global CAPM. The term $(\varphi \pi)_{i}$ measures the proportion of domestic risk unexplained by the global CAPM $\left(\omega_{i}^{\varepsilon}\right)$ internationally priced because of market segmentation. Intuitively, $(\varphi \pi)_{i}$ can be seen as a measure of stock market segmentation and should vary between 0 and 1 depending on national and international market structures. It can be inferred empirically from data.

Finally, we can write (25) as:

$$
E\left(R_{i}\right)-r=\lambda \operatorname{Cov}\left(R_{i}, R_{w}\right)+\lambda(\pi \varphi)_{i} \omega_{i}^{\varepsilon}
$$


Our model, represented by equation (26), assumes barriers that capture explicit and implicit factors that affect the decision of investors to access international assets. Despite its apparent simplicity, this model is powerful enough to provide empirical content to the time-varying world stock markets structure. It says that if markets are partially segmented, expected returns are not only related to the world market portfolio, but will also require a super risk premium to compensate the investors for not holding perfectly diversified portfolios.

To sum up, the main conclusion of previous theoretical international CAPMs for partially integrated markets [Black (1974), Stulz (1981), EL-85, EL-89 and the models developed in the vein of these works] was that assets to which all investors access are priced using the traditional global CAPM as if the markets were integrated whereas to hold ineligible securities investors would generally require a super risk premium proportional to the differential risk aversion and the conditional market risk. Unlike these models, we establish that if a group of investors does not hold the world market portfolio because of explicit and/or implicit barriers on inflows and/or outflows, the remaining investors are also unable to hold the world market portfolio and thus a part of the domestic risk can be priced to compensate rational global investors for an inability to hold the well diversified world market portfolio.

\section{Proposition 3}

If a group of investors do not hold all international assets, the world market portfolio is not efficient and the traditional global CAPM must be augmented by a new factor that reflects the proportion of the domestic risk made undiversifiable internationally by markets segmentation. The more the markets become integrated, the more the premium required on this additional risk factor decreases and the lower the international cost of capital.

\section{4- Strict segmentation}

If because of direct or indirect barriers, investors exclusively invest in their respective domestic assets, markets are strictly segmented. In that case, the undiversifiable domestic risk in equation (26) is entirely priced. The same analysis drives to the 
traditional domestic CAPM. For the asset $i$ from the country $d$, the domestic CAPM can be written as:

$$
E\left(R_{i}\right)-r=\beta_{i}^{d}\left(E\left(R_{i}^{d}\right)-r\right)
$$

where $E\left(R_{i}\right)$ and $E\left(R_{i}^{d}\right)$ are the expected returns on the asset $i$ and on the market portfolio of country $d$, respectively. $\beta_{i}^{d}$ is the beta of asset $i$ with respect to the market portfolio of country $d$.

Equation (27) can also be written as:

$$
E\left(R_{i}\right)-r=\lambda_{i} \operatorname{Cov}\left(R_{i}, R_{i}^{d}\right)
$$

where $\lambda_{i}=\frac{E\left(R_{i}\right)-r_{i}}{\sigma_{i}^{2}}$ is the domestic price of market risk in country $i$ and $\sigma_{i}^{2}$ is the variance of the domestic market portfolio $i$.

This model suggests that expected returns in a strictly segmented market are determined by their systematic risk with respect to the domestic portfolio.

\section{3- An Illustration: Cost of Capital Differences}

If markets are neither fully integrated nor strictly segmented, the required return on corporate investments has to be computed using our partially integrated CAPM (equation 25). In general, this will yield to a different cost of equity than the models that hold in the two extreme cases of perfect integration (equation 9) and strict segmentation (equation 27). However, in practice, only domestic and rarely global CAPMs are used by practitioners and researchers to compute the cost of capital [Brounen et al. (2004) and Durnev et al. (2004)]. The aim of this section is to empirically examine whether, when markets are partially integrated, our partially integrated CAPM leads to a different estimation of the cost of capital than the traditional domestic CAPM and global CAPM. Concretely, we investigate the difference between each of these models for firms from several developed and emerging countries. 
Let $\theta_{i}$ be the difference between the expected rate of return on firm $i$ obtained from the domestic CAPM and the partially integrated CAPM, and $\delta_{i}$ the differences between the expected return obtained from the global CAPM and the partially integrated CAPM. If markets are partially integrated, $\theta_{i}$ and $\delta_{i}$ will differ from zero for most firms, but by how much? To answer this question, we assess $\theta_{i}$ and $\delta_{i}$ for a sample of firms from markets that have different degrees of integration into the world market. More precisely, we consider firms from Brazil, Canada, France, Malaysia, Mexico and the US. MSCI national indexes with gross dividend reinvestment are used to proxy world and national portfolio market indexes. Data on individual firms are extracted from DataStream International and the International Finance Corporation databases. Data are monthly and our sample period goes from January 2000 to December 2010. We consider that the US is the reference country and thus we express all returns in US dollar. Our models are estimated under the hypothesis of rational expectations using quasi-maximum likelihood approach and allowing errors to follow a $\operatorname{GARCH}(1,1)$ process.

For the extreme case of complete integration, expected cost of equity of the firm $A$ from the country $i$ is obtained from regressing returns on firm $A\left(R_{i, t}^{A}\right)$ on returns on the world market portfolio $\left(R_{w, t}\right)$ as in the following empirical version of the global CAPM:

$$
\begin{aligned}
& R_{i, t}^{A}-r_{t}=\beta_{A, t}^{w}\left(R_{w, t}-r_{t}\right)+\varepsilon_{A, t} \\
& h_{A, t}^{2}=\alpha^{A}+\gamma^{A} \varepsilon_{A, t-1}^{2}+\theta^{A} h_{A, t-1}^{2}+\xi_{A, t}
\end{aligned}
$$

where $h_{A, t}^{2}$ is the empirical measure of the variance of the asset $A$ and $\beta_{A, t}^{w}$ is the coefficient beta of the asset $A$ with respect to the world market portfolio.

In the case of strict segmentation, the cost of equity of the firm $A$ from the country $i$ is obtained from the estimation of the following conditional version of the domestic CAPM:

$$
\begin{aligned}
& R_{i, t}^{A}-r_{t}=\beta_{A, t}^{i}\left(R_{i, t}-r_{t}\right)+\varepsilon_{A, t} \\
& h_{A, t}^{2}=\alpha^{A}+\gamma^{A} \varepsilon_{A, t-1}^{2}+\theta^{A} h_{A, t-1}^{2}+\xi_{A, t}
\end{aligned}
$$


where $R_{i, t}$ is the return on the market portfolio of country $i$ and $\beta_{A, t}^{i}$ is the coefficient beta of the asset $A$ with respect to this domestic market portfolio.

As for the partial integration case, we proceed in three steps. Since the theory predicts that the world price of risk $(\lambda)$ should be the same for each country, we estimate first the world equation of the model:

$$
\begin{aligned}
& R_{w, t}-r_{t}=\lambda h_{w, t}^{2}+\varepsilon_{w, t} \\
& h_{w, t}^{2}=\alpha^{w}+\gamma^{w} \varepsilon_{w, t-1}^{2}+\theta^{w} h_{w, t-1}^{2}+\xi_{w, t}
\end{aligned}
$$

where $h_{w, t}^{2}$ is the empirical measure of the variance of the world market portfolio.

This provides us with estimates of the world price of risk $(\bar{\lambda})$ and of the coefficients of the time-varying world variance $\left(\bar{h}_{w, t}^{2}\right)$. We then impose these estimates in the country estimations based on national indices to get the average degree of segmentation $\left((\varphi \pi)_{i}\right)$ :

$$
\begin{aligned}
& R_{i, t}-r_{t}=\beta_{i}\left(R_{w, t}-r\right)+\bar{\lambda}(\varphi \pi)_{i} \omega_{i, t}^{\varepsilon}+\varepsilon_{i, t} \\
& h_{i, t}^{2}=\alpha_{0}^{i}+\gamma^{i} \varepsilon_{i, t-1}^{2}+\theta^{i} h_{i, t-1}^{2}+\xi_{i, t}
\end{aligned}
$$

where $\omega_{i t}^{\varepsilon}=h_{i t}^{2}-\beta_{i}^{2} \bar{h}_{w, t}^{2}, h_{i t}^{2}$ is the empirical variance of market $i$ and $\beta_{i}$ is the coefficient beta of the market portfolio of country $i$ with respect to the world market portfolio.

Finally, we impose the estimated world price of risk $(\bar{\lambda})$ and country degree of segmentation $\left((\overline{\varphi \pi})_{i}\right)$ in the estimation of the equilibrium rate of return expected on each firm $A$ from the country $i$ :

$$
\begin{aligned}
& R_{i, t}^{A}-r_{t}=\beta_{A}^{w}\left(R_{w, t}-r_{t}\right)+\bar{\lambda}(\overline{\pi \varphi})_{i} \omega_{A, i}^{\varepsilon}+\varepsilon_{A, t} \\
& h_{i, t}^{A}=\alpha^{A}+\gamma^{A} \varepsilon_{A, t-1}^{2}+\theta^{A} h_{i, t-1}^{A}+\xi_{A, t}
\end{aligned}
$$


We have to notice that similar estimation strategies have been applied by Bekaert and Harvey (1995), Hardouvelis et al. (2006) and Carrieri et al. (2007) who note that, although a multi-step procedure has the drawback of including sampling errors, it is more in line with the theory and produces more powerful tests.

Table 1 summarizes estimation results. ${ }^{11}$ The average price of market risk is equal to $\bar{\lambda}=2.70$ and is highly significant, which is consistent with the findings of earlier studies. As expected, emerging stock markets are significantly more segmented than developed markets. According to our findings, the most segmented market is Mexico with an average degree of segmentation $\overline{\varphi \pi}=0.67$, followed by Malaysia $(\overline{\varphi \pi}=0.49)$ and Brazil $(\overline{\varphi \pi}=0.42)$. Our findings are comparable to those obtained using a different approach by Adler and Qi (2003) for Mexico and Carrieri et al. (2007) for a sample of emerging countries including Brazil, Malaysia and Mexico. As for developed markets, the US $(\overline{\varphi \pi}=0.04)$ and Canada $(\overline{\varphi \pi}=0.07)$ are highly integrated into the world market followed by France $(\overline{\varphi \pi}=0.19)$.

Table 1:

Summary of cost of capital differences

\begin{tabular}{|c|c|c|c|c|}
\hline Country & Nb of firms & $\begin{array}{l}\text { Average degree of } \\
\text { segmentation } \\
\left((\overline{\varphi \pi})_{i}\right)\end{array}$ & $\begin{array}{c}\text { Average absolute } \\
\text { value of } \theta_{i}\end{array}$ & $\begin{array}{c}\text { Average absolute } \\
\text { value of } \delta_{i}\end{array}$ \\
\hline Brazil & 106 & $\begin{array}{c}0.423 \\
(0.000)\end{array}$ & $\begin{array}{c}175.678 \\
(0.000)\end{array}$ & $\begin{array}{l}181.091 \\
(0.000)\end{array}$ \\
\hline Canada & 212 & $\begin{array}{c}0.069 \\
(0.000)\end{array}$ & $\begin{array}{l}22.247 \\
(0.031)\end{array}$ & $\begin{array}{l}15.338 \\
(0.045)\end{array}$ \\
\hline France & 131 & $\begin{array}{c}0.192 \\
(0.000)\end{array}$ & $\begin{array}{l}54.355 \\
(0.014)\end{array}$ & $\begin{array}{l}49.453 \\
(0.008)\end{array}$ \\
\hline Malaysia & 78 & $\begin{array}{c}0.486 \\
(0.000)\end{array}$ & $\begin{array}{l}123.433 \\
(0.000)\end{array}$ & $\begin{array}{l}85.435 \\
(0.000)\end{array}$ \\
\hline Mexico & 89 & $\begin{array}{c}0.670 \\
(0.000)\end{array}$ & $\begin{array}{l}97.396 \\
(0.000)\end{array}$ & $\begin{array}{c}198.771 \\
(0.000)\end{array}$ \\
\hline US & 517 & $\begin{array}{c}0.042 \\
(0.000)\end{array}$ & $\begin{array}{l}11.218 \\
(0.063)\end{array}$ & $\begin{array}{l}10.314 \\
(0.011)\end{array}$ \\
\hline
\end{tabular}

Notes: For each country, this table presents the number of firms, the average degree of segmentation and the absolute average cost of capital differences in basis points between the three competing models (the domestic CAPM, the global CAPM and the partially integrated CAPM). P-values are in parentheses.

More interestingly, the three models yield significantly different cost of equity estimates for most cases at the $1 \%$ level and in all cases at the $10 \%$ level. The highest

\footnotetext{
${ }^{11}$ In order to save space we do not report detailed results but they are available upon request from authors.
} 
absolute average value of $\theta_{i}$ is obtained for Brazil (176 basis points) whereas the highest absolute average value of $\delta_{i}$ is obtained for Mexico (199 basis points). The Firms from Brazil and Malaysia show absolute average values of $\theta_{i}$ greater than 100 basis points while firms from Brazil and Mexico show absolute average values of $\delta_{i}$ greater than 100 basis points. The average absolute differences between cost of equity estimates obtained from the three competing models (the domestic, global and partially integrated CAPMs) are significantly smaller for firms from developed countries and are in most cases lower than 50 basis points. Thus, from an economic perspective, the average absolute difference between costs of equity estimates does not seen very large for firms from highly integrated markets such as Canada and the US thanks to generally high correlations between local and global factors. Koedijk et al. (2002) compare the cost of equity using the domestic and the global CAPMs and report low differences for firms from Canada and the US. The authors explain this finding by the fact that for highly integrated markets such as the US and Canada the domestic CAPM prices indirectly global factors since these factors are already in the local market index.

\section{4- Conclusion}

Previous works on cost of capital in intermediate market structures often rely on ad-hoc econometric combinations of global and local risk factors. The findings of these works are rather heterogeneous and mostly inconclusive. In this paper, we first introduce a theoretical model to compute equilibrium expected asset returns in partially integrated markets. In contrast to previous works on international asset pricing, our approach is not to look into investors portfolio holdings directly but we simply consider that there are different types of investors' behavior and investigate the consequences of this assumption on international asset pricing and market structure. Specifically, we assume that because of institutional and/or behavioral factors not every investor is willing or able to hold assets from around the world in proportion to market capitalizations and thus to hold the market portfolio. We show that if some investors do not want and/or are unable to hold international assets, the remaining investors will be unable to hold the world market portfolio. After all, the first investors' holdings and the second investors' holdings together make up the entire world market. As the relative per capita supply of the stocks that the first investors hold in limited quantities or simply do not hold is high, the prices of these stocks will be relatively low. Thus, a local risk premium can be 
rationalized to compensate investors for the excess supply of some stocks. In that context, the traditional global CAPM continues to hold with regard to an altered supply/world market portfolio but it does not hold with regard to the actual world market portfolio. The traditional global CAPM must be augmented by a new risk factor that reflects the part of the country-specific risk undiversifiable internationally because of markets segmentation. The more the markets became integrated, the more the premium required on this additional risk factor decreases and the lower the international cost of capital.

Second, we employ our model to assess, under the hypothesis of partial segmentation, the pricing errors made by investors who use the domestic or the global asset pricing model to price assets and compute the cost of capital of firms. We show that the three models (our model, the traditional global CAPM and the domestic CAPM) yield significantly different cost of equity estimates in most cases and that differences between the estimated costs of equity are higher for firms from emerging markets characterized by high level of segmentation. For highly integrated countries, local and global risk factors are often highly correlated and the three models generally lead to close estimations of the cost of capital.

Our paper suggests many potential avenues for further research. First, the theoretical model we introduce can be extended to take into account deviations from PPP and exchange rate risk. Second, a generalization of our model to an intertemporal framework would allow a better specification of the model because investment and consumption opportunities are stochastic. Third, given that several available ICAPMs can be viewed as particular cases of our model, the later provides a convenient framework to distinguish between them empirically. In particular, like the EL-89 multicountry model, our model permits to investigate some issue that cannot be analyzed in a two-country framework such as dismantling investment barriers within an economic region. Moreover, our model has an advantage compared to the EL-89 model; removal of investment barriers between the segments can be partial. Finally, in terms of policy decisions, our model can be used to assess the consequence of reforms and liberalization on market efficiency and to understand regional integration dynamics. 


\section{REFERENCES}

1. ADLER M. and B. DUMAS (1983), "International Portfolio Selection and Corporation Finance: A Synthesis", Journal of Finance, n 38 , pp. 925-84.

2. ADLER M. and QI R. (2003), “Mexico's Integration into the North American Capital Market”, Emerging Economic Review, 4, pp. 91-120.

3. Arouri , M. E.-H. and Nguyen, D. K. . (2010). Time-Varying Characteristics of Cross-Market Linkages with Emperical Application to Gulf Stock Markets. Managerial Finance, 36(1), 57-70.

1. Arouri, M. Nguyen, D.K. and K. Pukthuanthong (2012) "An international CAPM for partially integrated markets: Theory and empirical evidence" Journal of Banking and Finance, 36, 2473-2493.

2. BAILEY W. and JAGTIANI J. (1994), "Foreign ownership restrictions and stock prices in the Thai capital market", Journal of Financial Economics, vol. 36(1), pp. 57-87.

3. BASAK S. (1995), "A general equilibrium model of portfolio insurance", Review of Financial Studies, 8, pp. 1059-1099.

4. Basak, S., Chabakauri, G., 2010. Dynamic Mean-Variance Asset Allocation. Review of Financial Studies 23, 2970-3016.

5. BEKAERT G. and C. HARVEY (1995), "Time Varying World Market Integration", Journal of Finance, 50(2), pp. 403-44.

6. BEKAERT G. and HARVEY C. (2003)," Emerging Markets Finance”, Journal of Empirical Finance, 10, pp. 3-55.

7. BEKAERT G., HARVEY C. and LUMSDAINE R. (2002), “The Dynamics of Emerging Market equity Flows", Journal of International Money and Finance, $21: 3$, pp. 295-350.

8. Bell D. (1995), "Risk, return and utility", Management Science, 41(1), pp. 23-30.

9. BHATTACHARYA U. and DAOUK H. (2002), "The World Price of Insider Trading", Journal of Finance, 57, pp. 75-108.

10. BLACK F. (1974), "International Capital Market Equilibrium with Investment Barriers", Journal of Financial Economics, 1, pp. 337-352.

11. BROUNENE D., DE JONG A. and K. KOEDIJK (2004), "Corporate finance in Europe: Confronting theory with practice", Financial Management, 33(4), pp. 74-101. 
12. CARRIERI F, ERRUNZA V. and HOGAN K. (2007), "Characterizing World Market Integration through Time", Journal of Financial and Quantitative Analysis, 42(4), pp. 915-940.

13. Charles A. (2010), "The Day-of -the-week Effects on the Volatility: The Role of the Asymmetry", European Journal of Operational Research, 202, pp. 143-152.

14. Chortareas, G., Kapetanios, G., 2009. Getting PPP right: Identifying meanreverting real exchange rates in panels. Journal of Banking \& Finance 33, 390404.

15. CLARK, E.; JOKUNG, O.; Kassimatis, K. (2011), "Making inefficient market indices efficient”, European Journal of Operational Research, 209(1), pp. 83-93.

16. COOPER I. and KAPLANIS E. (2000), "Partially Segmented International Capital Market Integration Budgeting", Journal of International Money and Finance, 43, pp. 287-307.

17. Cumming, D., Johan, S., Li, D., 2011. Exchange trading rules and stock market liquidity. Journal of Financial Economics 99, 651-671.

18. DE SANTIS G. and GERARD B. (1997), "International Asset Pricing and Portfolio Diversification with Time-Varying Risk", Journal of Finance 52, pp. 1881-1912.

19. DRAGOTA, V. and MITRIC, E. (2004), “Emergent capital markets`efficiency: The case of Romania", European Journal of Operational Research, 155, pp. $353-360$.

20. DURNEV A., MORCK R. and YEUNG B. (2004), "Value Enhancing Capital Budgeting and Firm-Specific Stock Returns Variation," Journal of Finance, 59(1), pp. 65-105.

21. EASLEY D. and M. O'HARA M. (2004), "Information and the Cost of Capital”, Journal of Finance.

22. ERRUNZA V. et LOSQ E. (1985), “International Asset Pricing under Mild Segmentation: Theory and Test“", Journal of Finance 40,pp. 105-24.

23. ERRUNZA V. et LOSQ E. (1989), “Capital Flow Controls, International Asset Pricing, and Investors' Welfare: A Multi-Country Framework", Journal of Finance, 44(4), pp. 1025-1037.

24. EUN, C. and S. JANAKIRAMAN (1986), "A Model of International Asset Pricing with a Constraint on the Foreign Equity Ownership," Journal of Finance, 41, pp. 897-914. 
25. Guesmi K. and Nguyen D (2011), "How Strong is the Global Integration of Emerging Market Regions? An Empirical Assessment”, Economic Modelling, vol. 28, No. 6, pp. 2517-2527, 2011.

26. GRAUER F., LITZENBERGER R. and STEHLE R. (1976), "Sharing Rules and Equilibrium in an International Market and Uncertainty", Journal of Financial Economics, 3, pp. 233-256.

27. HARDOUVELIS G., MALLIAROPOULOS and D. PRIESTLEY (2006), "EMU and Stock Market Integration”, Journal of Business, vol. 79, pp. 365-392.

28. HARVEY C (1991), “The World Price of Covariance Risk”, Journal of Finance, vol 46(1), pp. 111-57.

29. Huang X. (2008), "Portfolio selection with a new definition of risk", European Journal of Operational Research, 186(1), pp. 351-357.

30. Johnstone, D.J., Lindley, D.V., 2011. Elementary proof that mean-variance implies quadratic utility. Theory and Decision 70, 149-155.

31. KAROLYI A. and R. STULZ, (2002), “Are Financial Assets Priced Locally or Globally?", in Handbook of the Economics of Finance, Constantinides, Harris and Stulz editions, North-Holland.

32. Koedijk, C.G., C.J.M. Kool, P.C. Schotman, and M. A. van Dijk, (2001), "The Cost of Capital in International Financial Markets: Local or Global?," Journal of International Money and Finance, 21, pp. 905-929.

33. Levy, H., 2010. The CAPM is Alive and Well: A Review and Synthesis. European Financial Management 16, 43-71.

34. Li X., Z. Qin, S. Kar (2010),"Mean-variance-skewness model for portfolio selection with fuzzy returns », European Journal of Operational Research, 202(1), pp. 239-247.

35. MALKIEL B. and Y. XU (2006), "Idiosyncratic Risk and Security Returns" working paper.

36. MERTON R. (1987)"An Equilibrium Market Model with Incomplete Information”, Journal of Finance, pp. 483-544.

37. Pedersen C. S. (2000), "Separating risk and return in the CAPM: A general utility-based model”, European Journal of Operational Research, 123, pp. 628639.

38. ROSS S. A. (1976), "The Arbitrage Theory of capital Asset Pricing", Journal of Economic Theory, n4, pp.343-362. 
39. SHARPE W. (1964), "Capital Asset Prices: A Theory of Market Equilibrium under Conditions of Risk", Journal of Finance, n ${ }^{\circ}$, pp.725-742

40. SOLNIK B. (1974), “An Equilibrium Model of the International Capital Market," Journal of Economic Theory, 8, pp. 500-524.

41. SOLNIK B. (1983), "International Arbitrage Pricing Theory", Journal of Finance, 38, pp. 449-57.

42. STULZ (1981), “A Model of International Asset Pricing”, Journal of Financial Economics, n 9 , p. 383-406.

43. STULZ R. (1999), "International Portfolio Flows and Security Markets", in Martin Feldstein, Ed. International Capital Flows, University of Chicago Press.

44. STULZ R. (2005), "The Limits of Financial Globalization," Journal of Finance, vol. 60(4), pp. 1595-1638.

45. STULZ R. and WASSERFALLEN W. (1995), "Foreign equity investment restrictions, capital flight and shareholder wealth maximization: theory and evidence", Review of Financial Studies, 8, pp. 1019-1057.

46. STULZ, R.M., 1995, "The Cost of Capital in Internationally Integrated Markets: The Case of Nestlé," European Financial Management, 1, 11-22.

47. UPPAL R. (1993), “A general equilibrium model of international portfolio choice", Journal of Finance 48, pp. 529-553.

48. Wang J., P.A. Forsyth (2011), "Continuous time mean variance asset allocation: A time-consistent strategy", European Journal of Operational Research 209 (2011) 184-201.

49. Zhou, S., Kutan, A.M., 2011. Is the evidence for PPP next term reliable? A sustainability examination of the stationarity of real exchange rates. Journal of Banking \& Finance Forthcoming. 